\title{
Bio Gas Generation from Biodegradable Kitchen Waste
}

\author{
Srinvasa Reddy.N. ${ }^{1}$, Satyanarayana.S.V. ${ }^{2}$, Sudha.G. ${ }^{3}$ \\ ${ }^{1}$ Faculty, Caledonian College of Engineering, Muscat, Oman \\ ${ }^{2}$ Faculty, Caledonian College of Engineering, Muscat, Oman \\ ${ }^{3}$ Research Scholar, Rayalaseema University, Kurnool, Andhra Pradesh, India
}

\begin{abstract}
Generation of Solid wastes in general and biodegradable waste in particular is increasing at house hold level over the last two decades. Per capita generation of the waste has been increasing steadily due to population growth and changing socio-economic characteristics and cultural habits and varies from $250 \mathrm{~g}$ to $600 \mathrm{~g}$. Any material which can be decomposable by the action of microorganisms in a short period of time is called biodegradable Mostly food waste; vegetable peels and fruit pulp are biodegradable. These materials readily mix with the soil by the action of bacteria. During decomposition, these materials release carbon dioxide, methane, ammonia and hydrogen sulphide into the environment thereby contributes to air pollution and odour pollution. The gases that are released during the decay of biodegradable wastes can be captured for the economic utility and as well as to save the environment. An attempt is being made in this technical research paper to demonstrate the possibilities energy recovery from biodegradable kitchen waste that is collected from residential societies which can be utilized for the benefits of the society. Kitchen and food waste collected from a high end residential community of 300 families in Mumbai city suburbs is analyzed for the quantification of bio gas. Bio gas is captured through a fabricated anaerobic digester. Experimentation and results are discussed. The results are encouraging.
\end{abstract}

Keywords-Anaerobic digester, Biodegradable Kitchen and Food Waste; Bio gas from Food Waste.

\section{INTRODUCTION}

Biodegradable waste is the waste that can be decomposed and will be broken down into carbon dioxide, water, methane or simple organic molecules by the action of micro-organisms in reasonably less time. These wastes are generated out of human and industrial economic activity and the sources could be the residential areas, commercial areas and industrial areas. Characteristics of these wastes vary depending upon its source of generation. The composition the waste varies from urban to rural and also from community to community due to their socio-economic -cultural and living conditions. Normally biodegradable wastes are food and kitchen waste, manure, agricultural and forestry waste, paper waste, and textiles. For the disposal wastes different disposal methods available and there is a need to select eco-friendly options to save the environment and natural resources.

Solid waste generated from the residential communities and also out of food processing, commercial and agricultural activity contain significant organic matter which are of biodegradable nature. The per capita waste generation rate in India has increased from $0.44 \mathrm{~kg} /$ day in 2001 to $0.6 \mathrm{~kg} /$ day in 2011 . The reasons for the increase in solid wastes are by changing lifestyles and increased purchasing power of urban Indians. There are 53 cities generate 86,000 TPD (31.5 million tons per year) of MSW at a per capita waste generation rate of 500 grams/day (Annepu, 2012[1]). Non availability of data and also inconsistency in available data on solid wastes are the major hurdle while studying the solid waste management process among Indian cites. At present more than 32\% of country's population is living urban areas and wastes generated in 366 Indian cities contribute $70 \%$ of solid waste from India's urban population. Estimations made by different agencies and institutions reported that the total MSW generated in urban India at 68.8 million tons per year (TPY) or 188,500 tons per day (TPD). The data collected indicate a $50 \%$ increase in MSW generated within a decade since 2001. In a "business as usual scenario", urban India will generate 160.5 million TPY (440,000 TPD) by 2041, in the next decade, urban India will generate a total of 920 million tons of municipal solid waste that needs to be properly managed in order to avoid further deterioration of public health, air, water and land resources, and the quality of life in Indian cities[2]. Also from the studies conducted and also analysis of solid waste samples collected from different cities across the country in India reveal that 
composition of urban Municipal Solid Waste (MSW) in India constitute $51 \%$ organics, $17.5 \%$ recyclables (paper, plastic, metal, and glass) and $31 \%$ of inert materials. The moisture content of urban MSW is $47 \%$ and the average calorific value is $7.3 \mathrm{MJ} / \mathrm{kg} \quad(1745 \quad \mathrm{kcal} / \mathrm{kg})$.

Aim: The aim of the study is to convert biodegradable kitchen waste in to bio-gas.

- To convert biodegradable kitchen waste into biogas.

Objectives:

- To produce a renewable bio energy from kitchen waste.

- To reduce air pollution.

- To find ecofriendly disposal methods

- To generate revenue from the waste that is generation of wealth from the waste.

- $\quad$ To reduce global warming.

\section{REVIEW OF LITERATURE}

Biogas refers to a gas made from anaerobic digestion of kitchen waste. Methane is a clean gas which generates energy and one of the main constituent of cooking gas. Abundant kitchen waste (biomass) in terms vegetable peelings, kitchen waste, food waste are abundantly available from the each and every house of Indian communities. These kitchen waste biomass mass can be a source for Methane production where combination of waste treatment and energy production would be an advantage. In this connection many researches carried studies and investigations for the generation of bio gas the Methane from biodegradable waste.

Dr. Anand Karve (President Appropriate Rural Technology of India, pune ARTI[3],[4] developed a compact biogas system that uses starchy or sugary feedstock material and the analysis shows that this new system is 800 times more efficient than conventional biogas plants.

Hilkiah Igoni[5] (2008) studied the Effect of Total Solids concentration of Municipal Solid Waste on the Biogas Produced in an Anaerobic Continuous Digester. The total solids (TS) concentration of the waste influences the $\mathrm{pH}$, temperature and effectiveness of the microorganisms in the decomposition process. They investigated various concentrations of the TS of MSW in an anaerobic continuously stirred tank reactor (CSTR) and the corresponding. Shalini sing, sushil kumar, M.C. Jain, Dinesh kumar (2000), [6] carried studies on cattle dung and their residues insemination with kitchen waste and found that the increased biogas production using microbial stimulants. Ranjeet Singh, S. K. et.al [7]collected inocula www.ijeab.com from four different sources such as Jajmau tannery waste treatment plant (ITW), Jajmau municipal waste treatment (IMW), Unnao distillery (IDW) and batch reactor and carried studies for the generation of waste. Jong Won Kang et al (2010) [8]studied the On-site Removal of H2S from Biogas Produced by Food Waste using an Aerobic Sludge Bio filter for Steam Reforming Processing. They show that a bio filter containing immobilized aerobic sludge was successfully adapted for the removal of $\mathrm{H} 2 \mathrm{~S}$ and $\mathrm{CO} 2$ from the biogas produced using food waste. Abhishek et.al (2015)[9] carried research on production of bio-gas from the food and degradable waste. Leta Deressa etal (2015)[10] analysed the production of bio gas from fruit and vegetable waste mixed with cow dung in anaerobic digester Sudha.G.et.al, 2012[11] published a paper titled "Production of biogas from different fruit pulp". Anaerobic digestion process was adopted to convert the biodegradable fruit pulp into biogas. It was observed that the more the Chemical Oxygen Demand (COD) in fruit pulp, the more is the biogas. COD value is directly proportional to biogas production.

\section{RELEVANCE}

Kitchen waste is organic material having the high calorific value and nutritive value to microbes, that's why efficiency of methane production can be increased by several order of magnitude, using higher efficiency and size of reactor. The bio gas used can be used for cooking and lighting purposes. And also on large scale generation the cost of biogas production is reduced. Also in most of cities and places, residential communities, hostels of university campuses, agricultural market yards, fruits and vegetable market huge amounts of bio degradable wastes are generated and are being disposed on to the landfill or discarded in open dumping yards. The traditional methods of bio degradable wastes results in public health hazards and diseses like malaria, cholera, typhoid. Inadequate management of wastes like uncontrolled dumping bears several adverse consequences: It not only leads to polluting surface and groundwater through leachate and further promotes the breeding of flies, mosquitoes, rats and other disease bearing vectors. Also, it emits unpleasant odour \& methane which is a major greenhouse gas contributing to global warming. Hence forth the kitchen waste can be used as a raw material to produce biogas. The produced biogas can be used as a cooking gas in the kitchen. This concept is energy from waste. 
IV. BENEFITS OF BIO GAS TECHNOLOGY

- Production of energy.

- Transformation of organic wastes to very high quality fertilizer.

- Improvement of hygienic conditions through reduction of pathogens.

- Environmental advantages through protection of soil, water, air etc.

- Micro-economic benefits by energy and fertilizer substitutes.

- Macro-economic benefits through decentralizes energy generation and environmental protection.

\section{MATERIALS AND METHODS}

The bio degradable waste materials used for the demonstrative study are vegetable peelings, fruit peelings, food waste collected from the residential housing societies. In Siddartha Nagar, Kandivili East at Radha Residence CHS there are about 300 families with a population of about more than 1200 people are living. From the house hold survey and from the society office registers it has been revealed that on an average $400 \mathrm{~kg}$ of exclusive organic waste is collected from house to house. The kitchen waste has been used for the demonstration of the experiment.

For the demonstration, the technology used by ARTI Appropriate Rural Technology of India, Pune (2003) has been used. At ARTI developed a compact biogas plant which uses waste food rather than any cow dung as feedstock, to supply biogas for cooking. The plant is sufficiently compact to be used by urban households. The design and development of this simple in this the bio gas plan uses waste grain flour, spoilt grain, overripe or misshapen fruit, nonedible seeds, and fruits.

Yet powerful technology for the people, has won ARTI the Ashden Award for sustainable Energy 2006 in the Food Security category. Dr. AnandKarve (ARTI) developed a compact biogas system that uses starchy or sugary feedstock and rhizomes, green leaves, kitchen waste, leftover food, etc. Just $2 \mathrm{~kg}$ of such feedstock produces about $500 \mathrm{~g}$ of methane, and the reaction is completed with 24 hours.

For the generation of the bio-gas an anaerobic digester is fabricated to convert biodegradable kitchen waste (BKW) into biogas. The digester can be a hard plastic tank or iron tank. The volume of the tank is designed based on the quantity of BKW produced per day. Cow dung or animal dung is added initially to introduce anaerobic bacteria into the digester. A Non-return valve (NRV) is fitted to both inlet and outlet pipes of the digester.
VI.

DESCRIPTION OF THE PARTS OF THE PROCESS

Slurry preparation tank: The kitchen waste is made into slurry with $45-50 \%$ solids. Initially $10 \%$ cow dung is required. At a later stage it can be reduced to $5 \%$. The process is a batch process. Each batch can be retained for 4 days in the digester.

Digester A digester is a huge vessel where chemical or biological reactions are carried out. Anaerobic digestion is a series of processes in which microorganisms break down biodegradable material in the absence of oxygen. It is used for industrial or domestic purposes to manage waste and/or to release energy. The digestion process begins with bacterial hydrolysis of the input materials to break down insoluble organic polymers, such as carbohydrates, and make them available for other bacteria. Acidogenic bacteria then convert the sugars and amino acids into carbon dioxide, hydrogen, ammonia, and organic acids. Acetogenic bacteria then convert these resulting organic acids into acetic acid, along with additional ammonia, hydrogen, and carbon dioxide. Finally, methanogens convert these products to methane and carbon dioxide. The digester is made up of fiber material like a plastic tank or steel tank.

Valves: A valve is a device that regulates, directs or controls the flow of a fluid (gases, liquids, fluidized solids, or slurries) by opening, closing, or partially obstructing various passageways. In an open valve, fluid flows in a direction from higher pressure to lower pressure. The ball screw valve is made by plastic material.

Gas Purifier The gas produced from digester consists of carbon dioxide, hydrogen sulphide and methane. The removal of both $\mathrm{H} 2 \mathrm{~S}$ and $\mathrm{CO} 2$ can be done by passing it through water. This simple process is used to produce a pure methane gas.

Pressure Gauge Many techniques have been developed for the measurement of pressure and vacuum. Instruments used to measure pressure are called pressure gauges or vacuum gauges. The pressure gauge is a device used to measure the pressure inside the digester. The pipe lines are made up of PVC (polyvinyl chloride). It's used to flow the waste crushed food into the digester and also to flow the gas from digester to gas purifier. The anaerobic digester develop in the pilot study is shown in the line diagram in figure- 1 below.

\section{Process flow sheet}

1. Slurry preparation tank

2. Anaerobic digester

3. Methane gas collection tank

4. Sludge collection tank. 


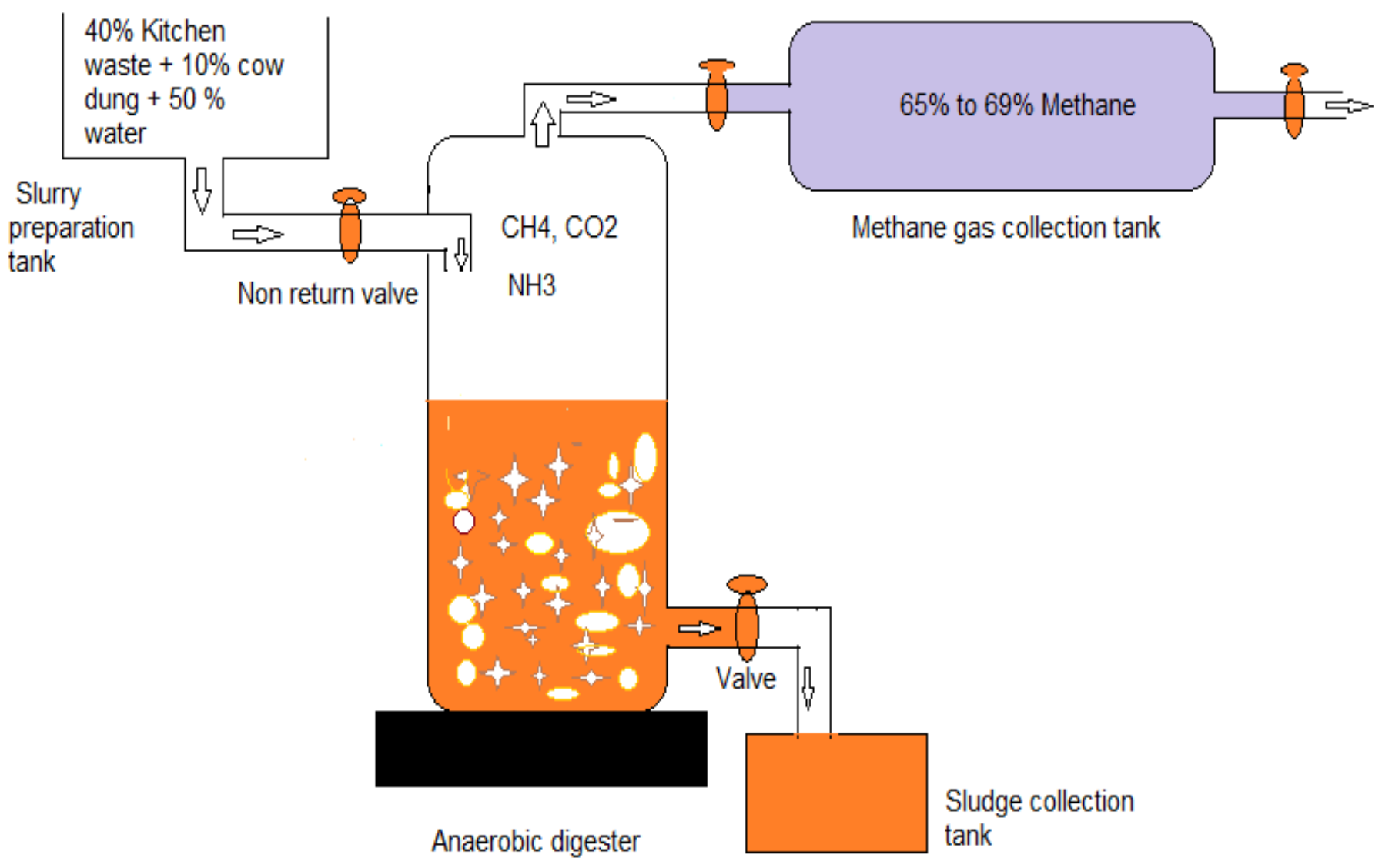

Fig.1: Anaerobic Digester Experimentation unit model

\section{EXPERIMENTAL PROCEDURE}

The fresh kitchen waste consisting of fruit pulp, vegetable peeling and food waste is mixed with cow dung and water to prepare slurry. The ratios are $40 \%$ kitchen waste plus $10 \%$ cow dung and $50 \%$ water. The slurry was pumped into an anaerobic digester tank. The tank was thermally insulated and was provided with a low speed agitator that worked continuously; under mesosphilic conditions $\left(38^{\circ} \mathrm{C}\right)$. This slurry was transferred into the anaerobic digestion tank and retained nearly for 96 hours. After 96 hours of maturation time due to micro bacterial actions and anaerobic digestion in the absence of oxygen different gases such as Methane, Ammonia, Carbon dioxide and sulphur dioxide are generated. Methane gas was collected in a separate gas collection tank. The sludge from the anaerobic digester is collected in a sludge collection tank, which can be used as a bio-fertilizer.

\section{DESCRIPTION OF METHOD}

The biodegradable kitchen waste (BKW) is made into slurry by adding suitable, quantity of water. The slurry is introduced into the anaerobic digester through the inlet pipe. Nearly 10-kilogramme cow dung slurry is passed into the digester. The microorganisms decompose BKW into Carbon dioxide and methane. The methane gas is collected in a storage tank through the outlet pipe.

$$
\text { BKW + Cow dung + Water } \rightarrow
$$

Methane + Carbon dioxide + ammonia

\section{RESULTS AND ANALYSIS}

The percentage of methane varies from $65 \%$ to $69 \%$ and carbon dioxide varies from $15 \%$ to $25 \%$. The remaining $\%$ is ammonia and hydrogen sulphide. The percentage of methane can be increased by decreasing the carbon dioxide percentage in the anaerobic digester.

\section{Waste characteristics}

Waste is collected from a sample of ten housing units in a residential community of 300 residential fats. The waste are collected for a period of seven days and the average collection per day per house is reported in the table below. The housing community selected for the study is Radha Residency, Siddarth Nagar, Borivili (E) situated in Mumbai western suburbs. 
Table.1: Analysis of Bio degradable waste and food waste is collected from Radha Residency Community of 300 Residential

\begin{tabular}{|c|c|c|c|c|c|c|}
\hline \multicolumn{7}{|c|}{ Flats } \\
\hline House no & $\begin{array}{l}\text { No of } \\
\text { persons in } \\
\text { Housing unit } \\
\text {-Flat }\end{array}$ & $\begin{array}{c}\text { Wet } \\
\text { Waste } \\
\text { Kg/dayFlat }\end{array}$ & $\begin{array}{c}\text { Dry Waste } \\
\text { Kg/day /Flat }\end{array}$ & $\begin{array}{l}\text { Total Waste } \\
\text { kg/day/flat }\end{array}$ & $\begin{array}{c}\text { Per Week wet } \\
\text { waste } \\
\text { Collection } \\
\text { from the } \\
\text { Sample housing } \\
\text { units in } \\
\text { kg/day/flat }\end{array}$ & $\begin{array}{c}\text { From the } \\
\text { Housing } \\
\text { Society(300Flats) } \\
\text { in } \mathrm{Kg} / \text { week }\end{array}$ \\
\hline 1 & 4 & 0.8 & 1 & 1.8 & 5.6 & 168 \\
\hline 2 & 4 & 1 & 1.2 & 2.2 & 7 & 210 \\
\hline 3 & 5 & 1.5 & 1.4 & 2.9 & 10.5 & 315 \\
\hline 4 & 4 & 0.88 & 1.2 & 2.08 & 6.16 & 184.8 \\
\hline 5 & 5 & 1.25 & 1.4 & 2.65 & 8.75 & 262.5 \\
\hline 6 & 6 & 1.44 & 1.47 & 2.91 & 10.08 & 302.4 \\
\hline 7 & 4 & 0.92 & 1.06 & 1.98 & 6.44 & 193.2 \\
\hline 8 & 5 & 1.2 & 1.3 & 2.5 & 8.4 & 252 \\
\hline 9 & 3 & 0.66 & 0.735 & 1.395 & 4.62 & 138.6 \\
\hline 10 & 3 & 0.63 & 0.84 & 1.47 & 4.41 & 132.3 \\
\hline
\end{tabular}

From the table of analysis it is seen that on an average about 2 tons of biodegradable waste is collected from the residential community of 300 flats. Bio degradable kitchen waste mix is analyzed in the laboratory and the results of the mix are furnished below.

Table.2: Characteristics of kitchen waste

\begin{tabular}{|l|l|l|}
\hline Sl.No & Description & $\mathbf{g} / \mathbf{K g}$ \\
\hline 1 & Total Solids & 250 \\
\hline 2 & $\begin{array}{l}\text { Organic Total } \\
\text { Solids }\end{array}$ & 280 \\
\hline 3 & aNo3-N & $<0.11$ \\
\hline 4 & aNHp4-N & $<0.2$ \\
\hline
\end{tabular}

\section{Results and Discussions:}

At residential community, Radha Residency co-operative housing society where in about three hundred families are staying and generating about two tons of BKW per week and is disposed on to open land dumping following the conventional methods of disposal . On pilot study experimentation it is revealed the $\mathrm{BKW}$ can be used in this project can be used to generate biogas. For demonstration purposes a fixed drum type model is used in the pilot study. From the lab scale experiment 75:25 Ratio of food waste and cow dung will provide more efficient gas. From this experiment it is recorded that it is able to produce around $4500 \mathrm{ml}$ of biogas daily in a 8 liter reactor (digester).

\section{CONCLUSIONS}

The gap between demand and supply for energy sources can be reduced by converting Bio degradable kitchen waste into a biogas. It is a source of renewable green energy. The biogas can be used as a cooking gas and also can be used in turbine to generate electricity. The left over sludge can be packed and used as a manure and compost for agriculture forming. There is need, further to investigate the cost economics and utility returns to establish the plant and running the unit for 365 day a year at residential community level.

\section{REFERENCES}

[1] Ranjith Kharvel Annepu (2012) 1 Sustainable Solid Waste Management in India. Thesis report for the award of Master of Science in Earth Resources Engineering Department of Earth and Environmental Engineering, Foundation School of Engineering and Applied Science Columbia University in the City of New York January 10, 2012.

[2] Akolkar, A.B. (2005). Status of Solid Waste Management in India, Implementation Status of Municipal Solid Wastes, Management and Handling Rules 2000, Central Pollution Control Board, New Delhi. 
[3] Karve .A.D. (2007), Compact biogas plant, a low cost digester for biogas from waste starch. http://www.artiindia.org.

[4] Karve of Pune A.D (2006). Compact biogas plant compact low-cost digester from waste starch. www.bioenergylists.org.

[5] Hilkiah Igoni, M. F. N. Abowei, M. J. Ayotamuno and C. L. Eze (2008), Effect of Total Solids Concentration of Municipal Solid Waste on the Biogas Produced in an Anaerobic Continuous Digester. Tanzania Traditional Energy Development and Environment Organization (TaTEDO), BIOGAS TECHNOLOGYConstruction, Utilization and Operation Manual.

[6] Shalini Singh, Sushil Kumar, M.C. Jain, Dinesh kumar (2000), the increased biogas production using microbial stimulants. Indian Academy of Sciences.78 (3), pp.313-316.

[7] Ranjeet Singh, S. K. Mandal, V. K. Jain (2008), Development of mixed inoculum for methane enriched biogas production. Indian J Microbiology.. 2010, 50(1), pp.26-33.

[8] Kang, J.W., Jeong, C.M., Kim, N.J. et al.(2010) Onsite removal of $\mathrm{H} 2 \mathrm{~S}$ from biogas produced by food waste using an aerobic sludge bio filter for steam reforming processing. Biotechnology and Bioprocessing Engineering.15(3),pp.505-511.

[9] Abishek Joel J., Murali G., Ravishankar., Sibichakravarthy M., \& Sundhirasekar (2015) Performance Analysis of Anaerobic Digestion to extract Biogas from Kitchen Waste International Journal of Scientific \& Engineering Research,6(3) 703 ISSN 2229-5518

[10] Leta Deressa et.al (2015) Production of Biogas from Fruit and Vegetable Wastes Mixed with different Wastes Environment and Ecology Research 3(3):pp. 65-71.

[11] Sudha.G. Satyanarayana.S.V.(2012).Production of Biogas from Different Food wastes. International Journal of Applied Environmental Sciences, 7(1) pp.17. 